\title{
Open innovation, networking, and business model dynamics: the two sides
}

Brigitte Gay

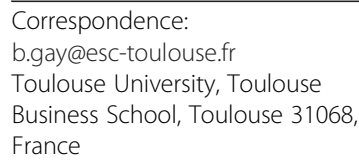

\begin{abstract}
A business model describes the design of the value creation and capture mechanisms needed to yield profit. We contend that for a business model to be viable in turbulent and hypercompetitive environments, its dynamics are important and must leverage, out of all key business model modules proposed in different studies, on a combined value and network perspective. These different elements present, however, distinctive challenges for small innovative companies and larger firms. Moreover, the business model of small firms is sited in the business models of their partners, big companies in particular. The purpose of this article is to highlight the importance of a dynamic network perspective and to understand how the networked business models in action of large firms may affect small innovative companies. We examine here the networked business models of big pharmaceutical companies and venture capital firms which interact in open innovation with small biotech companies.

Keywords: Open business models, Network dynamics, Strategy, Dependency, Innovation, Small business, Large firms, Value, Interdependency
\end{abstract}

\section{Background}

Entrepreneurs have to keep up today with an ever more complex, global, and dynamic environment. The term 'global innovation arms race' was used to highlight the competitive pressure that forces firms to accelerate their rates of innovation in products, services, and business models to keep up with others. Thus, companies need to develop business models that realize the value potential of novel technologies (Chesbrough and Rosenbloom 2002) in uncertain contexts.

The sale, licensing, and trading of technology have become a large-scale activity. Recent data demonstrate that the number of alliances per firm has gone up significantly, and it is common for large firms to manage over 500 alliances simultaneously (Hagedoorn et al. 2005). The recent emphasis on networked business models reflects that single companies cannot possibly master all the significant resources needed in $R \& D$, production, and marketing. By opening their business models through economic transactions, companies can be more effective in creating as well as capturing value. Firms thus leverage other companies' technologies, products, or organizational capabilities but also let other organizations leverage their assets.

Complex interorganizational networks and the individual business networks that lead to them are yet understudied, and empirical elaborations on networked business 
models are rare (Komulainen et al. 2006). A common proposition is that the firms' differential positioning within a network structure has an important impact on resource flows and hence on their performance. Moreover, firms are constrained by the continual strategic moves of others, and the different networks they are embedded in play an important role in influencing their performance as shown in a number of studies. Also, as value is exchanged or co-created between actors, a firm business model cannot be seen in isolation nor can it be considered static.

However, the crucial question of business model dynamics and interdependency has never been addressed. Many studies adopt a single-firm perspective and mostly seek to identify generic elements in a business model. In doing so, they ignore the necessary linkages between networked business models as well as possible heterogeneity among firms. Different firms will face different issues in managing the dynamics of networked business models and will have different objectives. Indeed, more than one type of firms populate today's changing environment driven by global and fast-paced competition. Companies are in reality predominantly quite small and short-lived, coming and going on a much smaller time scale than large firms. Interestingly, small firms are much more innovative than their larger counterparts (U.S. Small Business Administration 2007). Differentiating between small and medium enterprises (SMEs) and large firms is particularly relevant in high-technology industries. Many technological innovations fail commercially and SMEs lack tools to design their business models (Teece 2010).

This study fills a research gap by putting emphasis on business models' networking dynamics and interdependency, and on related issues faced by SMEs.

This study is exploratory. Theoretically, it builds on research on business models. We aim to highlight that two elements of a business model design, the value proposition and the network perspective, are linked and the principal components that define a business model dynamics. Furthermore, these two elements have very different significations for small innovative firms and large companies. The value proposition inherent to the business model concept implies very different strategic net perspectives for small and large firms. We also underline the need to address the consequences of the interdependencies of business models devised by very different firms that interact but have distinct resources and goals.

The empirical part of the paper presents the networking dynamics of the main firms, mainly large pharmaceutical companies and big venture capital firms, which interact in open innovation with small biotech companies. It seeks to place the three modules, value, networking, and dynamics in the context of large firms, and to examine the effect of their networking dynamics from an SME perspective. Indeed small companies, and particularly start-ups, depend heavily on deal flows and contracts with dominant market players for performance as well as on venture capital strategic financing. Consequently, entrepreneurs can only infer the outcomes of their small innovative firms if they understand the different global networks within which all firms operate and the open business models that dominant partners use to capture value/innovation as they interact with, or invest in, smaller entrepreneurial firms.

To date, the literature has been imbalanced in its strong emphasis on advantages of openness. We must pay closer attention to its consequences and differentiate between firms that base their business models on inbound (acquiring) innovation, players with financial resources, or outbound (selling) innovation, mostly smaller entrepreneurial 
firms. These firms are entwined in networks, and external firms within a business network have an influence on the process of management, including innovation management, of the firm developing its business model.

We choose the pharmaceutical industry as an appropriate context for our research setting, as it is an industry in which business models have changed with the impact of biotechnology and where the open innovation paradigm is undoubtedly in place (Chiaroni et al. 2009).

The paper is organized in the following way. First the theoretical premises of the study are discussed. I initially address the questions of the value proposition and its two facets, creating and capturing value, and what they imply for distinctive firms, small and large firms ('Business models: the ever-changing architecture of value' and 'The value proposition: open innovation, the big divide' sections). I then develop an understudied aspect of business models, the network perspective ('The network perspective: business model dynamics and interdependency' section). A representation of key elements and their linkages that form the basis for business model dynamics is established. Each element presents two opposite sides, and small innovative firms and large companies sit each mostly on one or the other side, deliberately or from lack of choice, forming quasi-oppositional business models. The environment in which the study was carried out is described in the Section 'Research Setting'. A small set of examples borrowed from the pharmaceutical industry is then used to represent the dynamics of the networked business models of large venture capital firms and major pharmaceutical companies as they maneuver in this industry ('The strategy of open innovation: how big players operate within and in-between networks' section). A discussion and conclusion follows regarding the impact of these models on innovative entrepreneurial firms ('Discussion and future directions - the entrepreneurial firm dilemma' section). Because open business models thrive on dynamic networking, I rely on software that has been specifically developed to allow visualizing the different firms in evolving networks. The data and software employed for analysis are described in Section 'Datasets and techniques for analysis of networking structural dynamics'.

\section{Business models: the ever-changing architecture of value}

Probably because it draws from a range of disciplines, the term business model is among the 'most sloppily used terms in business' and a variety of definitions exist (Magretta 2002).

The most basic functions of a business model are to seek to explain value creation and value capture. A business model is then simply defined as a basic representation of a firm's core logic and strategic choices for creating and delivering value to customers at an appropriate cost.

Teece (2010, p. 172) wrote:

Whenever a business enterprise is established, it either explicitly or implicitly employs a particular business model that describes the design or architecture of the value creation, delivery, and capture mechanisms it employs.

Included in this definition is that a business model is effective only when it allows the enterprise to yield a (high) profit. For Chesbrough and Rosenbloom (2002), business models indeed represent 'the architecture of the revenue.' A business model therefore 
articulates the logic of a value proposition. Its great strength is that it focuses attention on how key components in a system fit together and involves consideration of content as well as processes (Magretta 2002; Zott et al. 2010).

Within competitive and ever-changing environments, firms must constantly conceive and produce new value propositions, and hence rethink their business models. No matter what the sector or industry, designing a viable business model configuration should be an unending task. Scholars pertaining to the resource-based perspective consider the design of a strategy that makes the most effective use of resources as forming the essence of strategy formulation (e.g., Grant 1991). Scholars and entrepreneurs are ill-prepared for this, as there is no place in the economic theory for how to design a business. These studies assume away the architecture of the value and revenue proposition. As underlined by Teece (2010, p. 175), the price system does not resolve everything and 'equilibrium and perfect competition are a caricature of the real world'. Business model design is however needed to extend the central ideas in business strategy (Zott et al. 2010), make them form a coherent and convincing whole (Timmers 1999) or frame for action, and construct this frame or model around delivering value to the customer (Chesbrough and Rosenbloom 2002).

A number of articles seek to identify the generic elements of a business model. As many as nine independent modules have been proposed in a given study, and there is a lack of consensus from one study to another on which module should be regarded key. Business model components can be the market offering, distribution channel, value configuration, cost structure, revenue model, the architecture model, etc. Two modules regarding business models are studied here and assessed from both SMEs and large firms' perspectives. The first regards the value proposition and, more specifically, value creation and value capture. The second dimension is that a business model design and architecture involves the consideration of firms' networking activities and therefore of the interdependency of business models. Both dimensions are interrelated and should be considered key to business model dynamics.

\section{The value proposition: open innovation, the big divide}

The open business perspective epitomized by Chesbrough $(2003,2007)$ starts with the statement that open systems are today more successful than closed systems.

Closed systems describe companies that generate their own innovations in research and then develop, produce, market, distribute, and finance them on their own. Though open innovation practices have always existed, they were until recently more an ad hoc activity than a systematic one (Tschirky et al. 2000).

Open innovation principle allows penetrating novel technology, product, or market landscapes that extend beyond the actual core businesses of firms and that would be difficult to discover by individual organizations (Almirall and Casadesus-Masanell 2010). The terms 'inbound' and 'outbound' innovation have been coined by Chesbrough to depict the processes of exploiting internal innovation or acquiring external innovation, respectively. As clearly stated by Chesbrough (2003), open business models are in fact about dividing the work of innovation.

Teece (2010) has stressed that scholars need to pay attention not only to value capture but also to value creation, highlighting in particular that the value potential 
embedded in technologies needed to be realized. Indeed, basing its strategy on technological innovation is ever more difficult due to increased and often global competition, shorter product life cycles, and rising $R \& D$ costs. Whether innovators can actually profit from their innovations is hence a crucial question. Teece (2010) gives several examples of pioneer companies that failed to capture economic returns from innovation including Apple, Merck, Excite, and Lycos. An important issue companies need to face is that many innovative technologies often depend on complementary technologies, products, processes, etc. to yield value. Another is that the enterprise may not control all needed input and components along the vertical value chain of production, from manufacturing facilities to marketing channels and global contacts. Value will then accrue predictably to the owners of 'bottleneck' resource and material factors rather than to the inventors (Pisano and Teece 2007).

Many authors insist more on capturing value as a key element of business model design to achieve commercial viability. If the premise that powerful advantages will be conferred to any firms willing to open their business models, then this is especially evident for firms profiting from other firms' innovation. Open business models indeed attack the cost side (rising development costs) by leveraging external R\&D resources and the revenue side by licensing external technologies or products worldwide. These models are also more efficient to show shareholders a return on R\&D investments. Open business models therefore work best if a firm leverages the external development. Actually, when the open innovation principles or 'new rules of the new realities', as elaborated by Chesbrough (2003), are briefly summarized, the core of the model resides in that firms should leverage innovation outside ('not all the smart people work for us .... External R\&D can create significant value .... We don't have to originate the research to profit from it .... Building a better a better business model is better than getting to market first ....'). Openness is then mostly a strategy that allows rapid access to valued innovation worldwide while reducing operating costs and removing supply chain dependencies.

The benefits of open systems cannot possibly accrue equally to the other side, i.e., that of the sellers or young companies that can base openness only on their new, often unproven technology. Moreover, the business models of their partners affect necessarily young innovative companies.

In short, getting the business model to work regarding both value creation and value capture is good, while mastering value capture alone may be sufficient and not value creation as it does not necessarily imply value capture.

Consideration about open business innovation hence needs distinguishing between SMEs and large firms. The open business model has been developed essentially in the context of large multinational enterprises, drawing on case studies and interviews (e.g., Chesbrough 2003). Large firms have resources to develop inventions into products. They possess complementary assets, such as marketing and sales channels, that they use to induce SMEs to interact with them (Barney and Clark 2007). SMEs are nevertheless major actors in innovation (Maula et al. 2006), engage in innovation practices (Van de Vrande et al. 2009; Lichtenthaler 2007), and have the capacity for radical innovation. The question thus arises as to which type of firms actually harvests the value that highly innovative firms led by risktaking entrepreneurs create. 
An increasing issue for firms is that technologies are becoming complex and more often cannot be handled by a firm alone. Firms are hence driven to take an external perspective to resource allocation processes (Maula et al. 2006; Vanhaverbeke and Cloodt 2006). These forces even highly innovative companies to eventually participate in various forms of alliances. The growing use of external networks (Mytelka 1991) is then necessarily a major determinant of both SMEs and large firms 'competitiveness.' Moreover, because of their material and resource factor disadvantages, SMEs enter into contracts with big industrial groups (Mangematin et al. 2003).

The Profiting from Innovation Framework (Teece 2010) recognizes two business models used to capture value from innovation and by which firms can respond to new and changing technologies and markets (Teece 2010). They are extreme points of a continuum along which hybrid forms may exist. The first of these is the integrated business model, in which the firms control the whole value chain for their product offering. The other is the pure-licensing business model, which leverages on strong intellectual property rights that are licenced to other firms. The licensors retain ownership of their licensed assets. These are often small firms, hampered by their lack of financial resources and often unable to develop the final products by themselves. Their business model is to operate in the first phases of the value chain, generating revenues in the form of licensing payments, while licensees choose to rely partially or extensively on these upstream licensors to capture innovation.

In both cases, the business models leverage on value creation and capture. However, part of the value in the pure-licensing business model is lost to other firms.

Few scholars have however confronted the issues faced by small innovative firms capitalizing on their internal innovation and using outward IP licensing, even though these firms are major actors in the contemporary innovation landscape (Fosfuri 2006). Teece (1986) suggested that only firms operating in strong appropriability regimes should engage in licensing, as being original inventors did not guarantee that they would earn the 'lion's share' of the profit rather than licensees. Some innovative firms have technologies of general applicability that they can thus license to numerous ultimate customers. Moving towards such general purpose technologies has been considered a business model innovation (e.g., Gambardella and McGahan 2010). The innovative firm is considered less vulnerable in one-on-one negotiations with downstream licensees, and the sheer act of being able to expand the number of applications or downstream markets increases in effect its overall profit. However, these recent studies do not offer a vision of how this business model may fare with time as the technology is rendered rapidly obsolete and competitors arise.

\section{The network perspective: business model dynamics and interdependency}

The notion of business model is often only applied at the level of the industrial firm and remains a rather static concept. The recognition that interorganizational networks represent a key element in business models is recent (Komulainen et al. 2006; Westerlund et al. 2008). Yet, until 2000, scholars saw business models as making sense at the network level. Firms' position and role in business networks were deemed important (Axelsson and Easton 1992; Håkansson 1982). Value creation and value capture indeed occur within a value network, and not a linear sequence of activities, which constitutes 
a key element of the business model in that it can extend the company's own resources and include partners as well as suppliers, distribution channels, etc. (Hamel 2000). Firms can focus on specific activities while in- or out-sourcing others. For Zott and Amit (2008, p. 1), 'the business model is a structural template that describes the organization of a focal firm's exchanges with all of its external constituents in factor and product markets'. Open business models therefore must necessarily delve into alliance management (e.g., Lavie and Rosenkopf 2006; Rothaermel and Alexandre 2009). Importantly, the firm position in a value network and that of the firms it is interacting with may shift overtime and should be part of a business model (Chesbrough and Rosenbloom, 2002).

We contend two modules out of all modules proposed in different studies are the cornerstones to take into consideration to render a business model viable in turbulent and hypercompetitive environments: the value proposition and a networking perspective. Moreover, these two modules should be considered inextricably linked together to allow conducting business model dynamics, an essential component missing from models.

There are however issues in managing the dynamics of networked business models. Indeed, networking can also lead to risks as it embeds firms in ever-changing interorganizational webs, and site their business model in the possibly very different business models of their partners, especially that of large industrial companies but also big financial parties, such as venture capital firms. Any modification in a firm's business network can have consequences for the firm itself. In addition, a firm's business network may influence not only its business model but also that of the firms it interacts with. Afuah and Tucci (2000) view a business model as a 'system made-up of components, linkages and dynamics', offering thus a systemic perspective on how to do business and create/capture value. A firm business model changes overtime and this under the influence of actors in its network as they interact with the firm or disengage from activities with this firm (Doganova and Eyquem-Renault 2009). As written by Mason and Spring (2011, p. 1033), '..... business models and their practice might interact in an iterative and evolutionary way. Business models are not first designed and then implemented'. They should be thought as 'strategy-in-practice'.

Also, Shafer et al. (2005) have emphasized that many different actors interact in a value network and serve different functions. A company is in reality woven in the business model of distinct firms that have different objectives and values.

Indeed if we only consider SMEs and large firms, small firms need to rely heavily on networks, using licensing to transact business. Their smallness forces them to reconsider their boundaries since their inception rather than later as they have limited assets and need to leverage their technologies externally. SMEs cannot however capitalize for great durations on their existing technologies as these are short-lived and rapidly obsolete due to global and unending competition.

The business models of big organizations also lead to the formation of interorganizational networks. However, they will reflect more an organizational adaptation to major changes in the environment (Chesbrough, 2003). Large organizations need to reduce time to market, to acquire rapidly changing technologies, cope with increased competition and the blurring of industry boundaries. Acquiring assets can be done on a sustained basis and is potentially endless. 
Given these considerations a networking view of firms' business models is crucial. The dynamics of innovation practices in both small and larger firms is a research area that needs to be further developed (Van de Vrande et al. 2009). Moreover, how small and larger firms interact in open innovation has rarely been studied, though we know that large and small firms occupy very different positions in the value chain (Christensen et al. 2005) and that inequality in resources will mold the pattern of interactions between various organizations.

Overall, the implications of a networking perspective - business model networking dynamics, their different usage by small and large firms, and the necessary imbrications of business models possibly at the expense of some firms, in particular innovative firms have not been followed up. Figure 1 summarizes what we propose as the key and interconnected elements of business models in action, also gauged from the perspective of SMEs and large firms.

\section{Results and discussion}

\section{Research setting}

Open business models are not made in isolation. As firms interact with one another, they weave an ever-changing network of interactions into which they embed themselves and which may constitute an asset or a liability. For any company, the interdependency

\section{VALUE}

\section{NETWORKS}
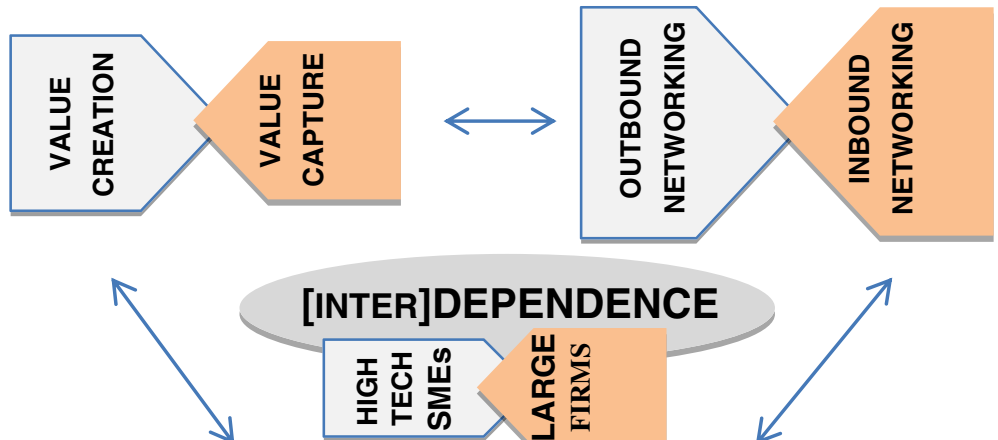

[INTER]DEPENDENCE
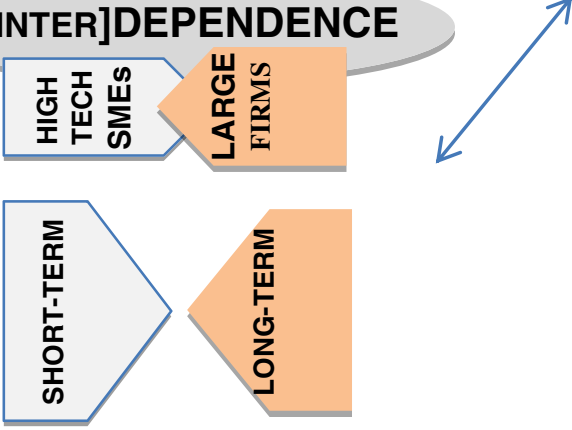

\section{DYNAMICS}

Figure 1 Our proposed key and interconnected elements of business models in action. Two cornerstones of business models, the value and the network perspectives, are effectively interlinked and the main levers for a third key module, business model dynamics. We seek to outline that when opening up the boundaries of their business models, high-tech SMEs and large multinational corporations find themselves on diametrically opposed sides within each of these modules, as highlighted in gray for small firms and in red for large firms. The three modules also involve necessarily the notion of dependence as companies are highly dependent on complementary resources and their partners' networking activities. In particular, small innovative firms lack financial and material resources and need to interact with large industrial companies that control those resources and with financial firms, such as venture capital firms. 
of many 'open' business models at play needs to be understood. A firm immerged in connected worlds can master its own business model only if it realizes that the business models of its partners can have a significant impact on its own performance and survival.

We used the pharmaceutical industry as an appropriate context for our study for analyzing and interpreting interfirm transaction networks, in particular, between small biotech companies and large pharmaceutical firms.

The pharmaceutical industry has adapted to its environment by increased outsourcing of R\&D and risks through alliances. It is a clear example of an industry where the open innovation paradigm is in place (Chiaroni et al. 2009). Terms that are found in the literature and define different business models are numerous and models vary through time. The old terms used to describe the closed business model of big pharmaceutical or biotechnology companies were FIPCO, or Fully Integrated Pharmaceutical Company, and FILCO, or Fully Integrated Life Science Company, respectively. The Technology Platform business model leverages on licensing technologies to downstream firms. Hybrid models include technology licensing models that allow building internal revenue streams; they are combined with product development to try to realize the upside of product sales. The Fully Diversified model is more recent and is based on large pharmaceutical companies expanding their core business into the provision of related products through in-licensing, collaboration, and mergers and acquisitions. Collaborative models have been predicted to be the business models of the future, though the question of how profits should be split between partners has not been addressed.

Partnering money is highly important for innovative biotech companies as it constitutes a large percentage of biotech funding, increasing from $42 \%$ in 2007 to $59 \%$ in 2008 (Huggett et al. 2009). Top deals in particular are made with large incumbent companies. For example, Genmab, a publicly traded international biotechnology company, announced in June 2012 an agreement with Novartis, a Swiss multinational pharmaceutical company, to use its DuoBody ${ }^{\text {ma }}$ technology platform to create and develop bispecific antibodies. Under the terms of the agreement, Genmab receives an upfront payment of US\$2 million. If all milestones in the agreement are achieved, the total potential value of the agreement to Genmab would be approximately US\$175 million, plus research funding and royalties.

Venture capital (VC) is another major source of investment provided by VC firms to high-technology firms to finance their growth and product development. VCs are financial go-betweens between the financial and economic spheres. They first raise funds from institutional investors and then make equity investments in companies.

However, very few biotech companies have demonstrated the ability to sustain profits in this very difficult industry (Pisano 2006). For Pisano, biotech is dominated by organizational structures and business models that are flawed and 'has always been an industry in search of a business model that works.' In particular, the majority of biotech firms never turn a profit and never survive more than a few years. In their final 2011 report, the Industrial College of the Armed Forces, Washington D.C. writes that the biotechnology industry 'accepts a high rate of failure for both products and companies.'

To tackle these issues and possibly devise appropriate business models for biotech firms, we need to understand the critical link between high-growth, high-technology firms and their main capital providers, who are the large players in the pharmaceutical 
and VC industries. How these two categories of actors operate in their respective spheres, economic and financial, and how they explicitly deal with entrepreneurial firms therefore has to be addressed, taking here a network perspective (Figure 2).

\section{Methods}

As the pharmaceutical industry is global, we have used for the analysis of the transactional activity of big pharmaceutical companies a comprehensive proprietary dataset that encompasses information about alliances, or formal contractual agreements, in the pharmaceutical industry worldwide. The database was compiled by querying specialized internet sites (leading sources for news releases and regulatory filings from companies throughout the world such as Business Wire and PRNewswire, as well as the companies' internet sites) for alliances made in this industry between 2001 and 2006. The data sample contains 3,909 companies and the number of deals is 8,160.

For the analysis of the transactional activity of big venture capital firms, the data was drawn from VentureXpert, a comprehensive database of venture capital funds, portfolio companies, and deals owned and managed by Thomson Financial and the only database officially endorsed by the National Venture Capital Association. Data from VentureXpert has been used extensively in studies of the venture capital industry. This paper examines the US VC market as it is by far the largest in terms of the amount of capital invested. The time periods examined here run from the first quarter of 1996 to the last quarter of 2008. During this time, 1,499 biotech companies received venture capital funding in the

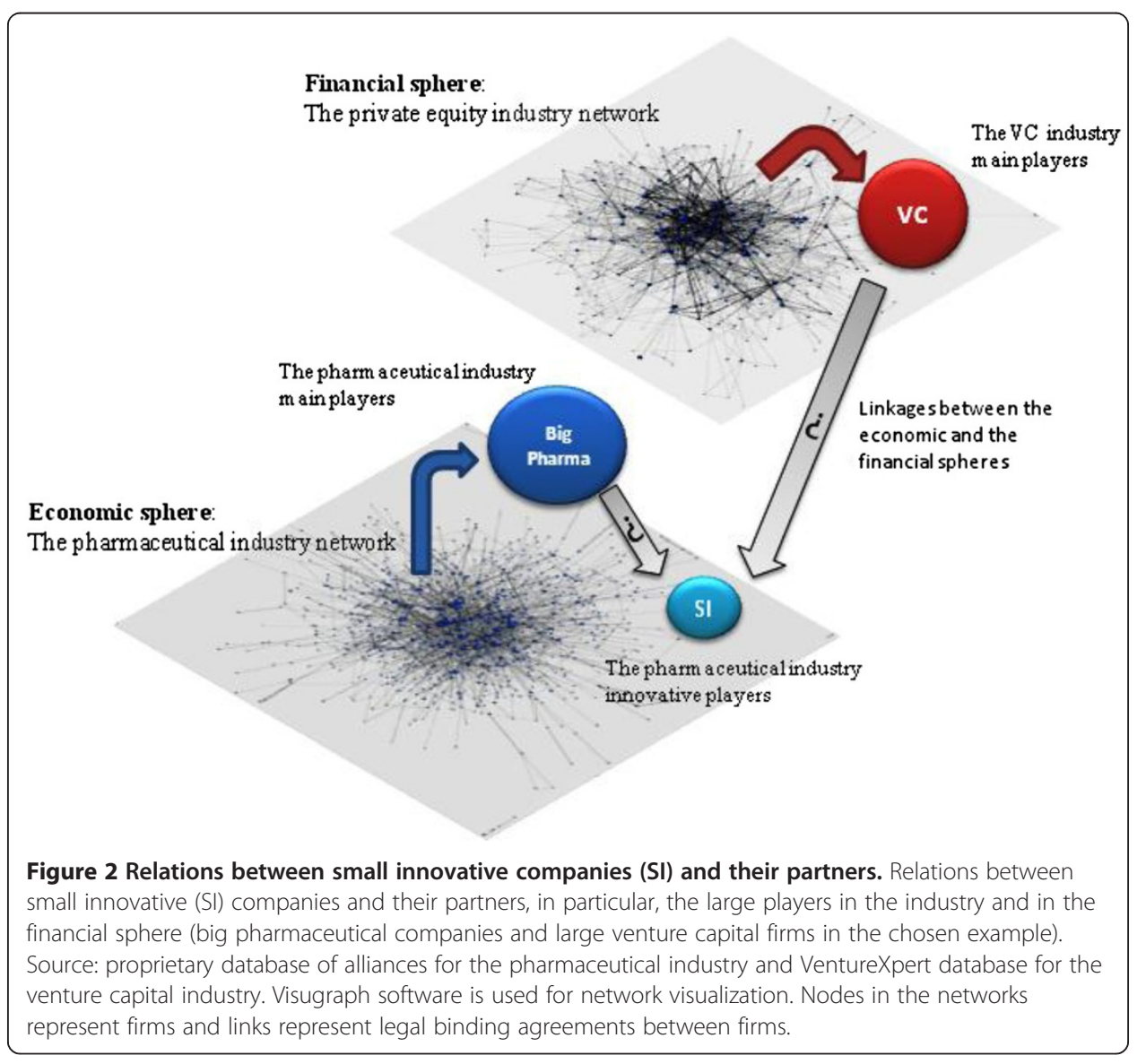


USA in either one round or more and 1,158 firms provided venture capital in 5,456 deals. We define a syndicated deal or syndication as the collection of VCs that invest in a given portfolio company, i.e., comprising those investing in a given portfolio company investment round as well as those investing in subsequent rounds. Many VC firms involved in syndications invest across a range of start-ups, creating a chain of investments in which the syndications form the links. Syndications thus define a network among VC firms, where the ties among them are their coinvestments (Kogut et al. 2007).

Empirical studies on business models are scarce and open innovation has essentially been analyzed in large multinational enterprises, drawing on case studies and interviews (e.g., Chesbrough 2003). One-dimensional summary statistics would filter out much of the interesting temporal and relational variation in the data (Moody et al. 2005). A dynamic interfirm network perspective implies that we engage data on these firms in new ways. We used VisuGraph software which was developed to visualize relational change (Gay and Loubier 2009). The recognition that visualization fosters theoretical insight for the study of social networks is recent, though visualization tools have always been the key elements in scientific advancement. As stated by Moody et al. (2005, p. 11), 'Dynamic maps provide a combined synthesis of information, allowing one to view the relevant abstract features of a given interaction system.'

VisuGraph software allows mapping of the temporal unfolding of firms' networked interactions and effectively displays their different network architectures as they vary through time. This force-directed graph drawing algorithm is original in that it produces a clockwise representation of time slices or periods allowing for a combined view of the graph dynamics.

The firms in the network are nodes, and the deals that connect them are edges or links. Temporal markers, representing distinct time periods, are distributed at the periphery of each graph in a clockwise manner, and each temporal marker will 'attract' only nodes that are active in its time period. The position of firms in a graph thus reflects the timing of their transacting activity. For example, nodes close to a given temporal marker represent firms which transact essentially during this time period, nodes in between two temporal markers are closer to the center of the graph and represent firms which transact during both time periods, while nodes in the center of the graph represent firms which transact equally at all times.

Nodes are represented by color-coded histograms giving the extent of the firm's transacting activity at each time period (from red for the first time period, changing progressively to green for the latest). When looking at a firm's evolving network, the histograms of its partners represent their alliance number within the total network of interfirm alliances and not with the firm alone. We can thus assess the duration of a partner's transacting activity within the overall network and if a firm's partners maintain themselves in the network for short or long time periods.

\section{The strategy of open innovation: how big players operate within and in-between networks}

Figure 3 depicts the unique and complex connected environments into which the different agents operate: the network of interfirm transactions in the pharmaceutical industry and the syndicated deals $\mathrm{VC}$ firms make in order to invest into innovative 


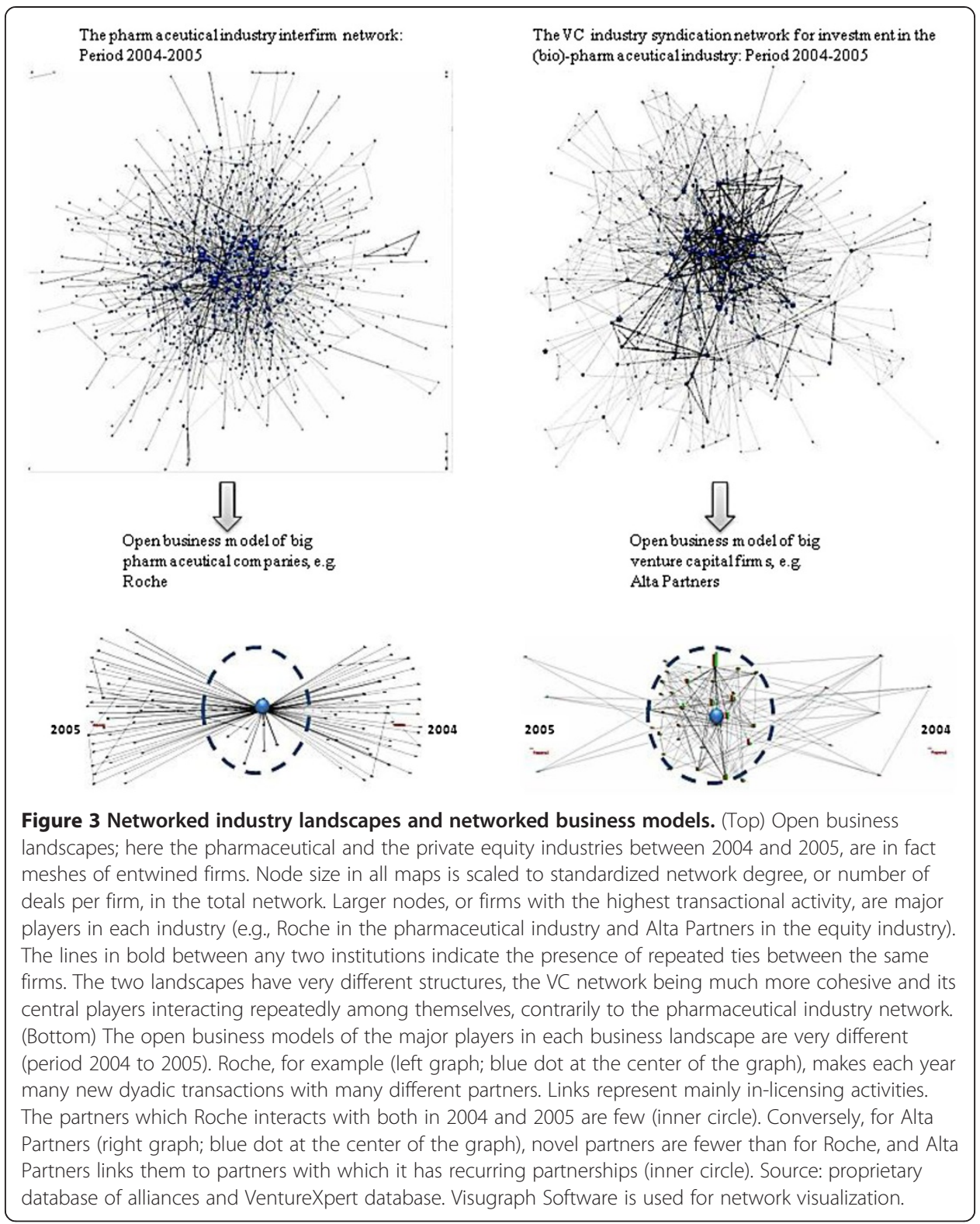

biotech companies. A syndicate is formed when two or more VC firms take an equity stake in an investment for a joint pay-off.

We find that in both cases, the largest pharmaceutical companies and VC players involved in their corresponding industries are the most active firms. However, their respective strategies are very different as are the interorganizational networks they operate into (Figure 3).

Big pharmaceutical companies essentially interact with many new and smaller partners on a yearly basis. For example, between 2004 and 2005, Roche, one of the largest pharmaceutical companies in the world, makes deals with 89 companies. There were 56 deals made in 2004 with 45 different companies and 61 deals with 50 companies in 2005, only 6 of which being made with previous partners (Figure 3).

Contrarily to big pharmaceutical companies, when they syndicate with other VCs, large VCs interact repeatedly with previous relations as well as conjointly develop new 
partnerships. For example, between 2004 and 2005, Alta Partners, a leading venture capital firm in life sciences founded in 1996, makes deals with $37 \mathrm{VC}$ firms. There were 35 deals made in 2004 and 40 in 2005 but $52 \%$ of the deals are repeated deals (Figure 3).

The top ten companies with the highest transacting activity in the pharmaceutical industry are all big pharmaceutical companies (Bayer, Novartis, Merck and Co., SanofiAventis, GlaxoSmithKline, Johnson \& Johnson, Roche, Pfizer, GE Healthcare, and Schering-Plough, bought by Merck in 2009) and make about $17 \%$ of all deals. Big pharmaceutical companies all make alliances with a pace of 30 to 100 deals every 2 years. Transactions are one-to-one, ad hoc, short-term, and global. This is illustrated in Figure 4 for period 2001 to 2006, taking Merck and Novartis as examples.

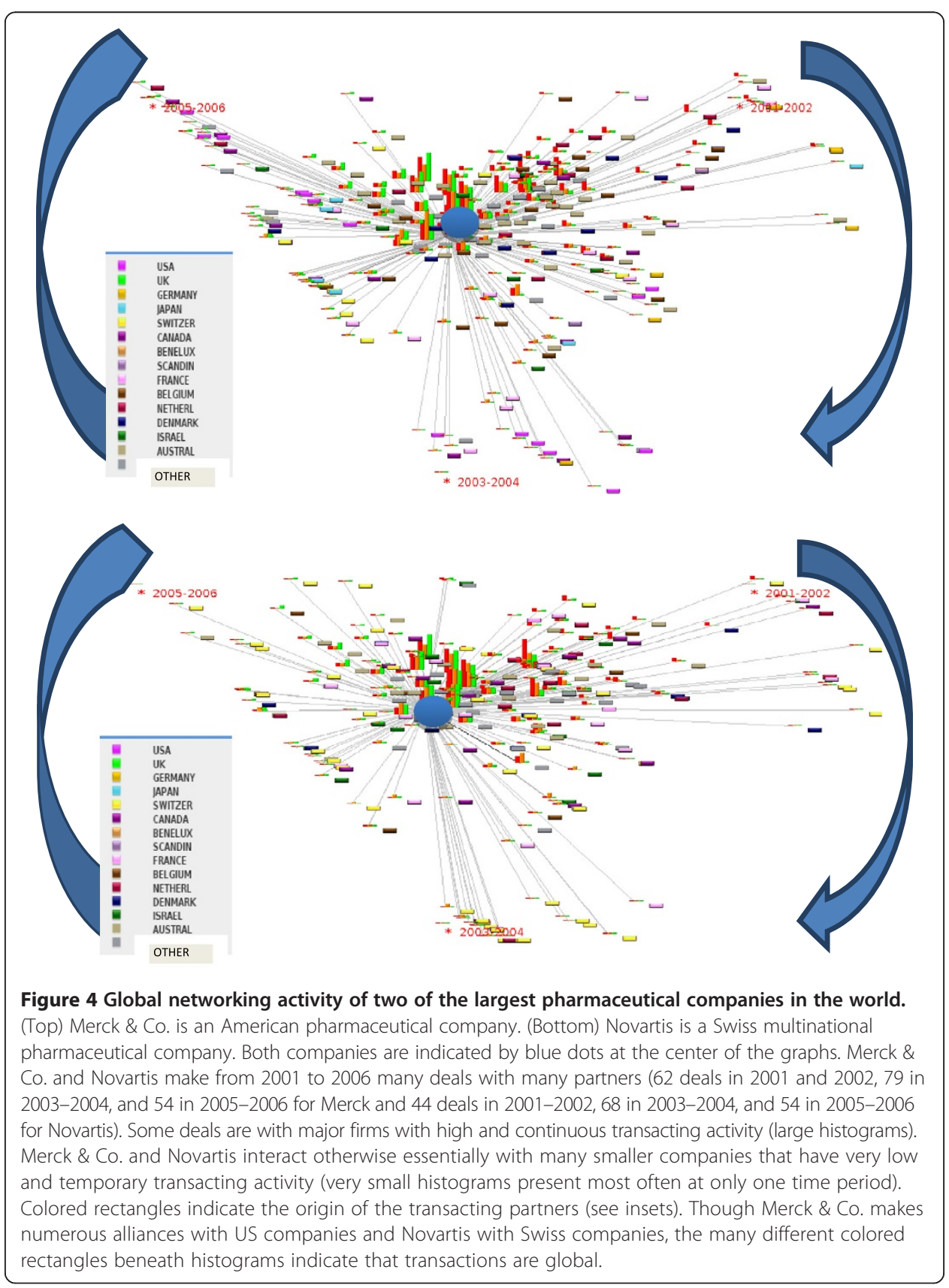


The alliance database reveals that big pharmaceutical companies mostly leverage external assets (in-licensing; value capture or inbound innovation) between 2001 and 2006. Seventy percent to as much as ninety percent of the transactions of big pharmaceutical companies are in-licensing agreements.

Conversely, biotech companies are in effect on the sell side of the open business model (out-licensing; value creation and outbound innovation) and typically gear toward explicit, short-term milestones.

A consequence of the constant search of new partners by dominant pharmaceutical companies is that it becomes extremely difficult for small companies to maintain themselves for an extended time in an industrial network. As illustrated in Figures 3 and 4, most firms that interact with big pharmaceutical companies have in effect low and temporary transactional activity within the whole network. The database reveals that about two thirds of biotechs active in a given period do not make alliances in the next period. Most biotech firms are not active in more than two periods.

Figures 5 and 6 illustrate how big VC firms operate for long time periods by looking at the behavior of two major VC firms. We find equivalent results for other major VC firms. Though extremely cohesive, networks between VCs evolve constantly and big VC firms rely on both major partners and a host of small VC firms that they interact with during shorter time periods.

Moreover, the cohesive business model of major VC firms allows them to invest rapidly in many biotech companies when deals are considered attractive, akin to big pharmaceutical companies. For example, Alta Partners has 464 ties with 153 known partners between 1996 and 2008, which allows it to invest as a result in 48 portfolio companies (Figure 6). Alta Partners repeats ties with 59\% of its partners overall.

We have also examined the exit strategy of venture capitalists. We found, in agreement with published results (Pisano 2006), that venture capitalists have overall very short-term horizons (3 years). Investments are also staged and milestones-driven to mitigate the risks.

Thus, on the 'buyers' side, be it equities or assets, business models function as wheels that move forward extremely fast as needed. Open 'wheel' practices on the buyer's side constitute a challenge for small innovative biotechs as they are basically made into commodities that any firm with capital can rapidly trade in the market place.

\section{Discussion and future directions-the entrepreneurial firm dilemma}

We need to consider firms, what they are and do, as a component part of the market. Interconnecting practices will shape markets which will, in turn, influence the architecture of business models. Though they are sometime implicit rather than explicit, business models are not abstract constructs. For business models to be (continuously) designed, it is important that specific, changing, and interconnected business environments are taken into account.

The scantiness of literature, whether theoretical or practical, on the subject is astonishing, especially in the context of innovation and globalization.

The present study emphasizes the importance of taking a network perspective to the study of business models in action. We also consider what the main cornerstones of business models - value creation and capture and firm networking activities - portend for different firms, small entrepreneurial firms, and large companies. We set out to explore connections between actions across multiple levels of analysis. 


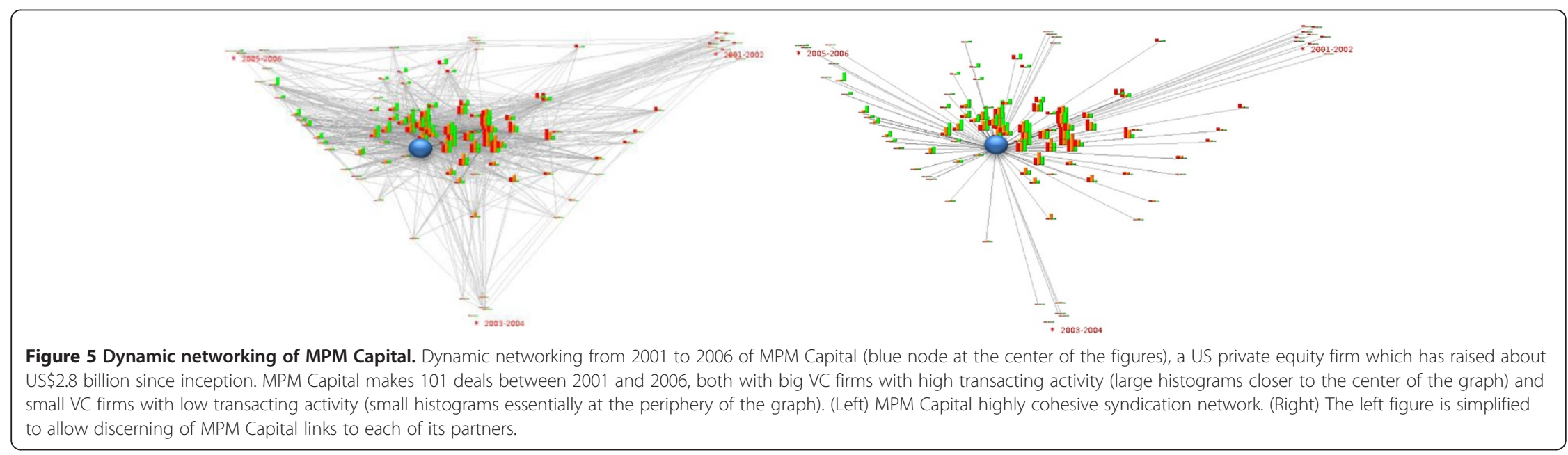




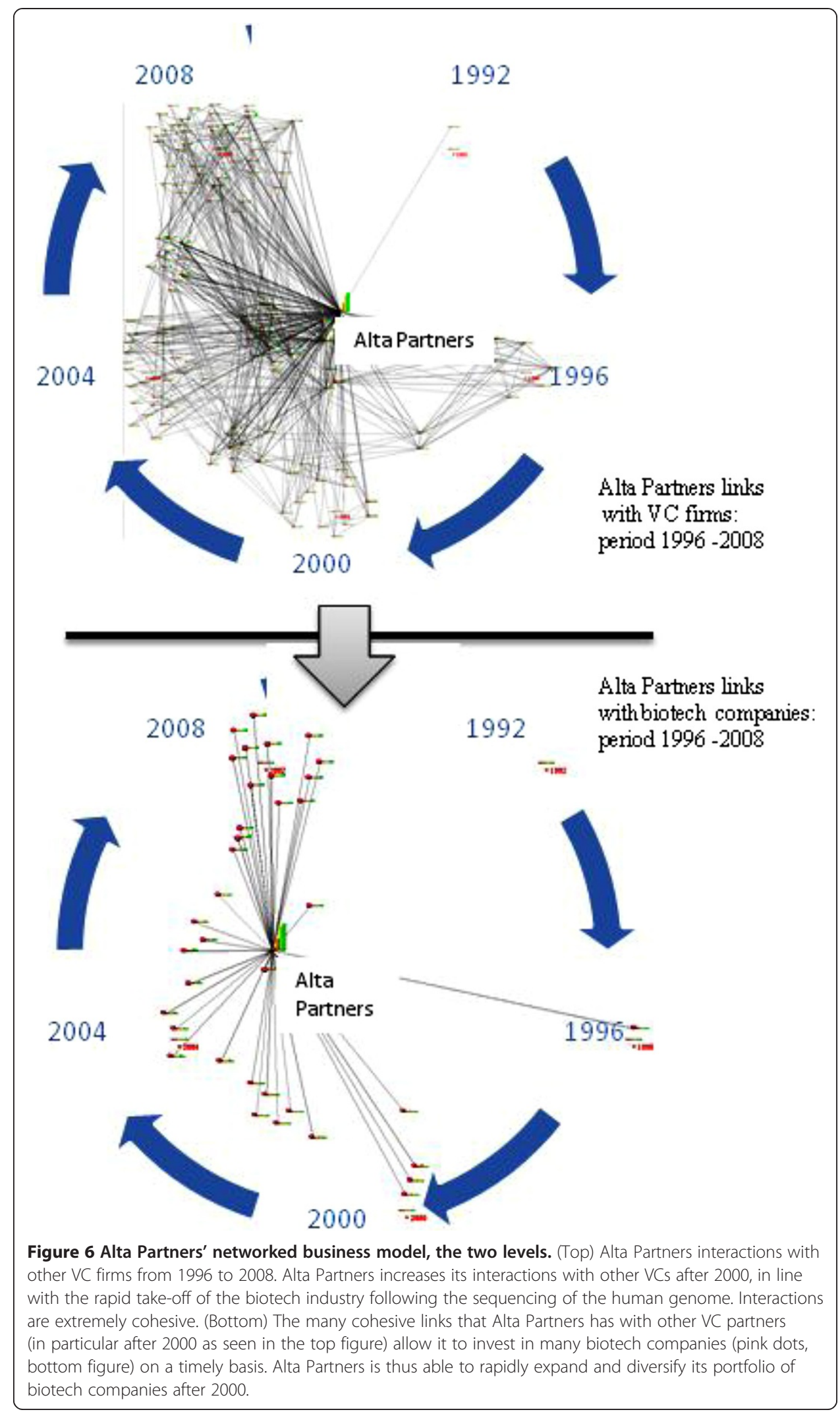


Though this study is preliminary, key points nevertheless stand out: the speed at which major actors transact allowing them to both expand and diversify their investments very rapidly, the persistence over time of large firms in both the pharmaceutical and the venture capital industry networks while small firms 'come and go,' as well as the dichotomous nature of exchanges in the pharmaceutical industry. Small and large firms indeed open their boundaries differently. Key modules that define a business model and its dynamics present each two facets that small and large firms do not use interchangeably. Activities are mostly one-sided, large and small firms sitting rather squarely on opposite sides, as illustrated in Figure 1 and by empirical results.

Another contribution of the article is to outline the necessary interdependency of open business models and, in particular, how business models on the 'buy' side affect business models on the 'sell' side in the pharmaceutical industry. Big pharmaceutical companies use in-licensing (inbound innovation) as a main contractual form. Linkages therefore constitute quasi-market mechanisms that give these large players the opportunity to continually grab valuable resources ceaselessly produced by a plethora of small firms, with competition amongst innovative firms being foremost. Repeat interactions are few and small innovative biotech firms are mainly used as commodities, their value equating that of their technologies or products.

Another important finding is that open business models can be structured very differently. Indeed, unlike that of big pharmaceutical companies, the business model of VC firms is based on repeated cohesive interactions with many partners. The endpoint is however the same, it allows rapid investment into many biotech companies for maximum profit and sustainable competitive advantage in uncertain environments. The two categories of major players, pharmaceutical companies and venture capital firms, when investing in life science use networks of alliances as a wheel to rapidly grab value in the form of open innovation as produced by smaller firms.

Pharmaceutical, biotech companies, and venture capital firms are intertwined in networks but their fate cannot be. Open innovation seems to benefit essentially larger players whether they belong to the financial or to the real sphere. Open innovation hence poses important challenges for SMEs even though they play a major role in the contemporary innovation landscape. These are important concerns from both business strategy and economic efficiency standpoints. Firms have differentiated and evolving strategies and develop very different business models according to distinct and specialized capabilities. Models hence cannot be generic. Moreover, general elements of a business model that are considered key in the literature have very different implications for small innovative companies and large firms. The study highlights the difficulty of developing ad hoc scenarios for SMEs due to the sheer imbalance between assets and the fact that their major partners are both looking for low-risk, fast-payback models.

The network analysis software used here highlights that openness in fact leads to (inter)dependencies which need to be investigated. Emphasis has also been brought on the fact that open business models are not static, they translate a firm organizational dynamics, and the wheels are turning very fast and partners come and go. Further research in this area is needed, in particular, regarding the different possible structures of open business models and the linkages between firms' distinct assets and potential models and outputs. 
Research on business models is often theoretical and business models are generally considered static thus missing dynamics, in particular, of networked value exchange. Such models may not help companies with distinct objectives and assets design their business. Table 1 summarizes, leveraging on the literature and our results, what we believe are the key points that should be further developed and viewed as interdependent to help firms elaborate business models in action.

They are both generally applicable and specific and can facilitate business model design. They however do not solve the entrepreneurial firm dilemma: its survival when assets are exchanged very fast and their value is limited by competition, fast obsolescence, long-term value creation, and the business models of large partners.

\section{Conclusions}

We have examined the networked business models of big pharmaceutical companies and venture capital firms which interact in open innovation with small biotech companies.

Some aspects of the pharmaceutical industry, such as the very long time-to-market and the high cost of R\&D, are not relevant in other contexts and put a major constraint on the business model and performance of innovative firms in that industry. However, some communalities are worth to mention and study in further research. A wellknown one is that the size distribution of business firms in an industry or for an entire population of firms is almost always highly skewed and satisfies a Pareto law over time, at least in the upper tail (Simon and Bonini 1958; Axtell 2001). In all industries that face a high degree of uncertainty, such as the pharmaceutical industry, we know it is not because firms are 'moving towards the equilibrium of the cost curve but have not reached it' (Simon and Bonini 1958, p. 608). Interfirm networks have also been found to have a Pareto degree distribution, a few firms making more links than many others. These hierarchical structures are dominated by large firms (see for example Powell

Table 1 A general framework for operating business models in action

\begin{tabular}{|c|c|}
\hline $\begin{array}{l}\text { Interdependent } \\
\text { module }\end{array}$ & Type/description \\
\hline \multirow[t]{4}{*}{ Open innovation } & Inbound \\
\hline & Outbound \\
\hline & Cumulative to integrate knowledge within and between areas \\
\hline & Innovative Business model \\
\hline \multirow[t]{3}{*}{ Networks } & Firm position \\
\hline & Network structure (firm and systemic level) \\
\hline & $\begin{array}{l}\text { (Inter)dependency - keeping track of competitors and (potential) partners' business } \\
\text { models, whether corporate and funding }\end{array}$ \\
\hline \multirow[t]{4}{*}{ Time element } & Change in business models \\
\hline & Dynamics of business models (networks and innovation) \\
\hline & Sector- and industry-level dynamics \\
\hline & Time horizon of development process \\
\hline \multirow[t]{2}{*}{ Business strategy } & Use of mixed and changing business models \\
\hline & $\begin{array}{l}\text { Diverse and innovative contracts with set milestones, and different levels of flexibility } \\
\text { and engagement between firms }\end{array}$ \\
\hline
\end{tabular}


et al. 2005 for the pharmaceutical industry). Radical innovations, generated by scientific breakthroughs, were necessary for some rare SMEs to reach the upper tail of a Pareto degree distribution in specific industrial sectors, but these highly innovative firms could not maintain their position overtime (Gay and Dousset 2005).

Pareto size and degree distributions highlight the heterogeneity in actors and behaviors and hierarchical structures. We have shown that the adaptive speed of large firms relied on their networking abilities (inbound networking) and was quite high, allowing them to better face changing environments. A substantial degree of turbulence was generated by the entry and exit of small firms which could not maintain themselves in the network. Future research is needed to accumulate more knowledge on the architectural dynamics of networks at organizational and industry level as well as about Pareto distributions and the underlying processes that generate them. This is especially important as collaborative models based on mutual benefits are often thought to be the ones that will count. They however will not stand up scrutiny if their structure and dynamics are not taken into account and particularly not only the speed of network connections of the focal firm but also that of other organizations in local as well as more globally fast-paced environments.

Competing interests

The authors declare that they have no competing interests.

Received: 12 September 2013 Accepted: 4 October 2013

Published: 14 Jan 2014

References

Afuah, A, \& Tucci, CL. (2000). Internet business models and strategies: text and cases (4th ed). New York: Irwin/McGraw-Hill. Almirall, E, \& Casadesus-Masanell, R. (2010). Open versus closed innovation: a model of discovery and divergence. Academy of Management Review, 35(1), 27-47.

Axelsson, B, \& Easton, G. (1992). Industrial networks: a new view of reality. London: Routledge.

Axtell, RL. (2001). Zipf distribution of US firm sizes. Science, 293, 1818-1820.

Barney, JB, \& Clark, DN. (2007). Resource-based theory: creating and sustaining competitive advantage. NewYork: Oxford University Press.

Chesbrough, H. (2003). Open innovation: how companies actually do it. Harvard Business Review, 81(7), 12-14.

Chesbrough, H. (2007). Why companies should have open business models. MIT Sloan Management Review, $48(2), 22-28$.

Chesbrough, H, \& Rosenbloom, R. (2002). The role of the business model in capturing value from innovation: evidence from Xerox Corporation's technology spin-off companies. Industrial \& Corporate Change, 11(3), 529-555.

Chiaroni, D, Chiesa, V \& Frattini, F. (2009). Investigating the adoption of open innovation in the bio-pharmaceutical industry, a framework and an empirical analysis. European Journal of Innovation Management, 12(3), 285-305.

Christensen, JF, Oleson, MH, \& Kjær, JS. (2005). The industrial dynamics of open innovation-evidence from the transformation of consumer electronics. Research Policy, 34, 1533-1549.

Doganova, L, \& Eyquem-Renault, M. (2009). What do business models do? Innovation devices in technology entrepreneurship. Research Policy, 38(10), 1559-1570.

Fosfuri, A. (2006). The licensing dilemma: understanding the determinants of the rate of technology licensing. Strategic Management Journal, 27(12), 1141-1158.

Gambardella, A, \& McGahan, AM. (2010). Business-model innovation: general purpose technologies and their implications for industry structure. Long Range Planning, 43(2-3), 262-271.

Gay, B, \& Dousset, B. (2005). Innovation and network structural dynamics: study of the alliance network of a major sector of the biotechnology industry. Research Policy, 34, 1457-1475.

Gay, B, \& Loubier, E. (2009). Dynamics and evolution patterns of business networks. Athens, Greece: Paper presented at the international conference on advances in social network analysis and mining (ASONAM).

Grant, RM. (1991). The resource based theory of competitive advantage: implications for strategy formulation. California Management Review, 33(Spring), 114-135.

Hagedoorn, J, Roijakkers, N, \& Van Kranenburg, H. (2005). Inter-firm R\&D networks: the importance of strategic network capabilities for high-tech partnering formation. British Journal of Management, 17(1), 39-53.

Håkansson, H. (1982). International marketing and purchasing of industrial goods: an interaction approach. Chichester, New York, Brisbane, Toronto, Singapore: Wiley.

Hamel, G. (2000). Leading the revolution. Cambridge: Harvard Business School Press.

Huggett, B, Hodgson, J, \& Lähteenmäki, R. (2009). Public biotech 2008-the numbers. Nature Biotechnology, 27(8), 710-721.

Kogut, B, Urso, P, \& Walker, G. (2007). Emergent properties of a new financial market: American venture capital syndication, 1960-2005. Management Science, 53(7), 1181-1198. 
Komulainen, H, Mainela, T, Sinisalo, J, Tähtinen, J, \& Ulkuniemi, P. (2006). Business model scenarios in mobile advertising. International Journal of Internet Marketing and Advertising, 3(3), 254-270.

Lavie, D, \& Rosenkopf, L. (2006). Balancing exploration and exploitation in alliance formation. Academy of Management Journal, 49(6), 797-818.

Lichtenthaler, U. (2007). The drivers of technology licensing: an industry comparison. California Management Review, $49(4), 67-89$.

Magretta, J. (2002). Why business models matter. Harvard Business Review, 2002, 33-36.

Mangematin, V, Lemarie, S, Boissin, JP, Catherine, D, Corolleur, F, Coronini, R, \& Trommetter, M. (2003). Sectoral system of innovation, SMEs development and heterogeneity of trajectories. Research Policy, 32(4), 621-638.

Mason, K, \& Spring, M. (2011). The sites and practices of business models. Industrial Marketing Management, 40(6), 1032-1041.

Maula, M, Thomas, K, \& Salmenkaita, JP. (2006). Open innovation in systemic innovation contexts. In H Chesbrough, W Vanhaverbeke, \& J West (Eds.), Open innovation: researching a new paradigm (pp. 241-257). Oxford: Oxford University Press

Moody, J, McFarland, DA, \& Bender-DeMoll, S. (2005). Dynamic network visualization: methods for meaning with longitudinal network movies. American Journal of Sociology, 110, 1206-1241.

Mytelka, LK (Ed.). (1991). Strategic partnerships and the world economy. London: Pinter.

Pisano, GP. (2006). Science business: the promise, the reality, and the future of biotech. Boston: Harvard Business School Press. ISBN 1-59139-840-1.

Pisano, GP, \& Teece, DJ. (2007). How to capture value from innovation: shaping intellectual property and industry architecture. California Management Review, 50(1), 278-296.

Powell, WW, White, DR, Koput, KW, \& Owen-Smith, J. (2005). Network dynamics and field evolution: the growth of interorganizational collaboration in the life sciences. American Journal of Sociology, 11(1), 132-1205.

Rothaermel, F, \& Alexandre, M. (2009). Ambidexterity in technology sourcing: the moderating role of absorptive capacity. Organization Science, 20(4), 759-780

Shafer, SM, Smith, HJ, \& Linder, J. (2005). The power of business models. Business Horizons, 48, 199-207.

Simon, H, \& Bonini, CP. (1958). The size distribution of business firms. American Economic Review, 48, 607-617.

Teece, DJ. (1986). Profiting from technological innovation: implications for integration, collaboration, licensing and public policy. Research Policy, 15, 285-305.

Teece, DJ. (2010). Business model, business strategy and innovation. Long Range Planning, 43, 172-194.

Timmers, P. (1999). Electronic commerce: strategies and models from business-to-business trading. Chichester: Wiley.

Tschirky, H, Escher, JP, Tokdemir, D, \& Belz, C. (2000). Technology marketing: a new core competence of technology-intensive enterprises. International Journal of Technology Management, 20, 459-474.

U.S. Small Business Administration. (2007). The Small Business Economy for Data Year 2006: a report to the President. http://www.sba.gov/advo/research/sb_econ2007.pdf (accessed October 29, 2013).

Van de Vrande, V, De Jong, JPJ, Vanhaverbeke, W, \& De Rochemont, M. (2009). Open innovation in SMEs: trends, motives and management challenges. Technovation, 29, 423-437.

Vanhaverbeke, W, \& Cloodt, M. (2006). Open innovation in value networks. In H Chesbrough, W Vanhaverbeke, \& J West (Eds.), Open innovation: researching a new paradigm (pp. 258-281). Oxford: Oxford University Press.

Westerlund, M, Rajala, R, \& Leminen, S. (2008). SME business models in global competition: a network perspective. International Journal of Globalisation and Small Business, 2(3), 342-358.

Zott, C, \& Amit, R. (2008). The fit between product market strategy and business model: implications for firm performance. Strategic Management Journal, 29(1), 1-26.

Zott, C, Amit, R, \& Masa, L. (2010). The business model: theoretical roots, recent developments and future research (p. 862). IESE Business Research Working Paper.

10.1186/2192-5372-3-2

Cite this article as: Gay: Open innovation, networking, and business model dynamics: the two sides. Journal of Innovation and Entrepreneurship 2014, 3:2

\section{Submit your manuscript to a SpringerOpen ${ }^{\circ}$ journal and benefit from:}

- Convenient online submission

- Rigorous peer review

- Immediate publication on acceptance

- Open access: articles freely available online

- High visibility within the field

Retaining the copyright to your article

Submit your next manuscript at $\boldsymbol{\wedge}$ springeropen.com 